\title{
FORECASTING THE FUTURE OF ISLAMIC EDUCATIONAL MANAGEMENT STUDY PROGRAM: PROJECTION OF NEEDS FOR LECTURERS
}

\author{
Nurul Hudha Purnomo \\ Islamic Educational Management Department, Institut Agama Islam Negeri Kediri, \\ Kediri, East Java, Indonesia \\ Email: hudhapurnomo@gmail.com
}

DOI: http://doi.org/10.33650/al-tanzim.v5i1.1549

\begin{tabular}{l|l|l} 
Received: September 2020 & Accepted: March 2021 & Published: March 2021
\end{tabular}

\begin{abstract}
:
The Islamic Educational Management program in IAIN Kediri was established in 2018 so that it requires proper planning to maintain the quality of the study program education. One of the planning steps is to maintain the ratio of the students and the lecturers by projecting the needs for lecturers. The method used in this research model is quantitative methods with the projection method, namely the growth rate and the input output, the parameter numbers used are the input rate and the graduate number, the assumption in this research is target so that the total of students can increase every year. The basic data used is the total of graduates, the total of new students and the total of lecturers. This research results in the number of needs for lecturers in the future. The results of this research reveal that in 2027, the number of lecturers needed for institutional courses will be 16 lecturers, while the number of lecturers for study program courses will increase to 25 lecturers. In 2028, the number of lecturers needed for institutional courses will increase to 18 lecturers, while the number of lecturers for study program courses will be 28 lecturers. Eventually in 2029 the number of lecturers in institutional courses will increase to 20 lecturers, while the number of lecturers needed for study program courses is 30 lecturers.
\end{abstract}

Keywords: Projections, Lecturers, Students

\begin{abstract}
Abstrak:
Program studi Manajemen Pendidikan Islam IAIN Kediri berdiri pada tahun 2018 sehingga membutukan perencanaan yang tepat untuk menjaga kulitas pendidikan program studi. Salah satu langkah dalam perencanaan tersebut adalah menjaga rasio dosen mahasiswa dengan melakukan proyeksi kebutuhan dosen. Metode yang digunakan pada model penelitian ini adalah kunatitatif dengan metode proyeksi yaitu dengan angka pertumbuhan dan masukan keluaran, angka parameter yang digunakan adalah angka masukan dan angka lulusan, asumsi yang digunakan adalah target sehingga jumlah mahasiswa ditargetkan terus meningkat pada setiap tahun. Data dasar yang digunakan adalah jumlah lulusan, jumlah mahasiswa baru dan jumlah dosen saat ini. Hasil dari penelitian ini pada tahun 2027 jumlah kebutuhan dosen mata kuliah institusi tetap 16 dosen sedangkan jumlah kebutuhan dosen mata kuliah prodi meningkat menjadi 25 dosen. Tahun 2028 jumlah kebutuhan dosen mata kuliah institusi meningkat menjadi 18 dosen sedangkan jumlah kebutuhan dosen mata kuliah prodi adalah 28 dosen. Dan terakhir pada tahun 2029 jumlah kebutuhan dosen mata kuliah institusi meningkat menjadi 20 dosen sedangkan jumlah kebutuhan dosen mata kuliah prodi adalah 30 dosen.
\end{abstract}


Kata Kunci: Proyeksi, Dosen, mahasiswa

INTRODUCTION

Higher education is one level of formal education to develop hard skills and soft skills from students. To achieve this, a well-planned educational management is needed. One of the substances in education management is human resource management (HR), which one of its functions is to manage educators and education personnel. According to (Widiansyah et al., 2019), one of the challenges for universities in particular human resources management is a professional lecturer present, where the College was able to produce graduates competent in their fields.

In HR management, the first management function to be carried out is the planning function. According to (Mangkunegara, 2003), human resource planning is the process of determining labor requirements based on forecasting development, implementing and controlling needs that are integrated with organizational planning in order to create the number of employees, appropriate and useful employee placement. Planning is a step to determine what will be done by considering all aspects so that it will minimize the form of failure in the implementation of activities. The form of activities in educational planning according to (Priyono, 2010) includes several activities, the first is planning and forecasting the demand for organizational manpower in the short and long term and the second is job analysis to ensure tasks, skills, objectives, abilities and knowledge required. According to (Armstrong \& Green, 2018), forecasting practice can be improved such that the accuracy of forecasts upon which decision makers in business and public policy depend is greatly increased. Enrollment forecasting is both an art and a science. Statistical techniques have improved significantly but still hard to come by and many events can influence actual path of prediction (Rakhimov \& Kankarej, 2015).

According to Chindia \& Wainaina (2014), forecasting is used to predict the future using data on hand or the formation of opinions. Forecasting is about predicting the future, but this can only be done based on information from the past, which raises the issue of how the most appropriate information and the corresponding model for predicting the future should be selected (Makridakis et al., 2020). In accordance with these activities, there is need forecasting in planning one of which is by doing projections.

Projection is a technique in planning to estimate future needs using growth figures. This technique is useful for compiling a master plan for the development of study programs in determining the needs for lecturers in the future. According to Ministry of Research Technology and Higher Education regulation No.2 of 2016 concerning the registration of educators in tertiary institutions in the attachment to chapter III c, it states that the ratio of lecturers to students is 1:45 in study programs of religious, humanities, social and applied sciences and 1:30 for science clusters, formal and natural sciences. This is confirmed by the Ministry of Research Technology and Higher Education in an article written by Priyatma (2015) as a tolerance limit because the target to be achieved is 1:30 for the social, religious and humanities clusters and 1:20 for the natural sciences. The plan is also contained in the assessment matrix on the higher education accreditation instrument version 3.0, namely that PT will get 
the maximum score if the ratio of lecturers to students is 1:30. Ministry of Research Technology and Higher Education in the news published by kompas.com (2015) stated that it would quarantine the campus which violated the ratio of the number of lecturers and students to improve its data. Setijaningsih and Handoyo (2012) also suggest that excess lecturers will cause no benefit, while lecturers shortage will cause less optimal learning.

Looking at some of these statements, it is very important in maintaining the ideal ratio between lecturers and students. Some important steps in maintaining this ratio include looking at the distribution of courses whether the lecturer assigned to teach is in accordance with their expertise or not. This step must be taken so that the quality of learning continues to run optimally.

To maintain the ratio of the number of lecturers to students, long-term planning is needed so that there is balance between the number of lecturers and students. The things that need to be considered include, among others, the lecturer retirement age, the increase in the number of students, the suitability of the lecturer's field of science with courses and full time equivalent teaching. This is needed as data to project the needs for lecturers from 2019 to 2029.

Islamic Education Management Study Program at IAIN Kediri is a new study program that has just entered its fourth year and will be preparing to apply for the accreditation process for the first time, in the process of submitting accreditation there are several documents that must be fulfilled, one of which is the study program planning document. One of the things in the planning is determining the needs for lecturers in the future. Seeing the importance of fulfilling the ratio of lecturers to students, researchers are interested in implementing one of the methods in educational planning, namely by carrying out educational projections to determine the needs for lecturers in the Islamic Educational Management Study Program at IAIN Kediri in 2019 to 2029.

\section{RESEARCH METHODS}

This research is quantitative research, quantitative research is "research that uses quantitative data for the purposes of analysis, so that in the data collection process measurement is carried out or can use available quantitative data (non-metric)" (Setyadin, 2005). This research design uses quantitative descriptive to reveal the data obtained so that it can be interpreted appropriately. The method used in this research model is the projection method, namely the growth rate and the input output, the parameter numbers used are the input number and the graduate number, the assumption used is the target so that the number of students is targeted to continue to increase every year. The basic data used is the number of graduates, the number of new students and the number of current lecturers.

The data is then projected to find out the growth rate each year, after which the data is described descriptively, where the data that has been collected is then processed and described based on the results of the calculation of educational projections in order to get the estimated results of the Islamic Educational Management Study Program at IAIN Kediri in 2019-2029. Data 
collection techniques in this study were to use primary data sources obtained from the Academic section of IAIN Kediri. The data needed in this study include the number of new students at IAIN Kediri from 2014 to 2019. Then another data is to collect lecturer data from the general section of IAIN Kediri. Furthermore, secondary data obtained by extracting data on the head of the Islamic Educational Management Study Program at IAIN Kediri. The data analysis procedure that was carried out for the first time was to compile the number of students in the last four years, then next was to calculate the growth rate, after the growth rate was found in the last four years, the last step was to project the number of student growth. The next step is to analyze the lecturers according to the courses being taught, and to project the number of lecturers' needs in the next 10 years.

\section{RESULTS AND DISCUSSION}

\section{Projected Number of Islamic Educational Management Study Program Students in 2019 - 2029}

This research was conducted at Islamic Educational Management Study Program (MPI). To perform data analysis related to the projection of needs for MPI lecturers, the first thing to do is to calculate the projected number of MPI students. The data needed in this study is the number of new students in the last 4 years, namely as follows;

Table 1 : Number of New Students of MPI study program 2017-2020

\begin{tabular}{ccc}
\hline Year & Number of Students & $\begin{array}{c}\text { Percentage of } \\
\text { increase per year }\end{array}$ \\
\hline 2017 & 66 & 0 \\
\hline 2018 & 132 & $100 \%$ \\
\hline 2019 & 129 & $-2.3 \%$ \\
\hline 2020 & 146 & $13.18 \%$ \\
\hline Total & 473 & \\
\hline Source: data on MPI study program accreditation in 2020
\end{tabular}

The table shows that in 2017 the MPI study program accepted 66 new students, then in 2018 there was an increase of 100\%, namely 132 students. In 2019 it decreased by $2.2 \%$ with 129 new students. In 2020 there is an increase of $13.18 \%$ with the number of new students of 146 people. From the basic data on the number of new students from 2017 to 2020, the projection of the number of new students until 2029 using the assumption of an increasing target is as follows;

Table 2: Projection of the Number of New MPI Students in 2017 - 2029

\begin{tabular}{lccc}
\hline & Year & $\begin{array}{c}\text { Number of New } \\
\text { Students }\end{array}$ & AP \\
\hline \multirow{3}{*}{ DATA } & 2017 & 66 & 0 \\
\cline { 2 - 4 } & 2018 & 132 & $100 \%$ \\
\hline & 2019 & 129 & $-2.3 \%$ \\
\hline
\end{tabular}




\begin{tabular}{llll}
\hline & 2020 & 146 & $13.18 \%$ \\
\hline & 2021 & 165 & $13.01 \%$ \\
\cline { 2 - 4 } & 2022 & 186 & $12.72 \%$ \\
\cline { 2 - 4 } PROJECTION 2023 & 209 & $12.36 \%$ \\
\cline { 2 - 4 } & 2024 & 234 & $11.96 \%$ \\
\cline { 2 - 4 } & 2025 & 262 & $11.96 \%$ \\
\cline { 2 - 4 } & 2026 & 293 & $11.83 \%$ \\
\cline { 2 - 4 } & 2027 & 327 & $11.60 \%$ \\
\hline 2028 & 365 & $11.62 \%$ \\
\hline
\end{tabular}

Table 2 shows that the last Data Growth Rate in 2020 was $13.18 \%$. This Growth Rate is then used as the basis for projecting the number of new students per year. The average growth rate from 2021 to 2029 is $12.06 \%$. With the assumption that the target increases, data on the number of new students in 2021 is 165 people with an increase in percentage of 13.01, then in 2022 the number of new students is 186 people with a percentage of $12.72 \%$. In 2023 the number of students was 209 with a percentage of $12.36 \%$, in 2024 the number of students was 234 with a percentage of $11.96 \%$, in 2025 the number of students was 262 with a percentage of $11.96 \%$, in 2026 the number of students was 293 with a percentage of $11.83 \%$. In 2027 there will be an increase so that the number of new students is 327 with the percentage growth rate of $11.60 \%$. In 2028 it increases to 365 with a percentage of $11.62 \%$ and in 2029 it increases to 407 students with an increase of $11.51 \%$.

In order to achieve the target of increasing the number of new students according to the projection results, there are several factors that support this. The first is good public relations management is needed to provide information to the public regarding the existence of the Islamic Educational Management Study Program. The second is reforming the study program governance which includes curriculum, learning, student management and lecturer placement. The third is increasing the capacity of lecturers, by encouraging MPI lecturers to at least have a functional position as Lector, encouraging senior lecturers to propose appointment as professors. This must be done so that the accreditation status of the study program gets maximum value, the advantage when the study program gets the maximum or superior score is that the study program can open more classes.

\section{Lecturer Distribution of Islamic Educational Management Study Program}

The curriculum Islamic Educational Management Study Program at IAIN Kediri was prepared by various parties, including the study program association, lecturers, students, alumni, and external stakeholders. The MPI curriculum contains courses on institutions, faculties and study programs. To project the lecturers' needs, other data needed besides the number of students is the number of lecturers at the MPI IAIN Kediri study program. The number of lecturers in the MPI study program is as follows; 
Table 3 : Data on the Number of MPI Lecturers

\begin{tabular}{lcccc}
\hline \multicolumn{1}{c}{ Status } & $\begin{array}{c}\text { Number of } \\
\text { Lecturers }\end{array}$ & $\begin{array}{c}\text { Principal } \\
\text { Lector }\end{array}$ & Lector & $\begin{array}{c}\text { Expert } \\
\text { Assistant }\end{array}$ \\
\hline $\begin{array}{l}\text { Permanent Lecturer of the } \\
\text { Study Program }\end{array}$ & 8 & 2 & 4 & 2 \\
\hline $\begin{array}{l}\text { Permanent Lecturers of the } \\
\begin{array}{l}\text { Study Program with } \\
\text { expertise outside the study } \\
\text { program }\end{array}\end{array}$ & 14 & 3 & 11 \\
\hline $\begin{array}{l}\text { Non-permanent Lecturer } \\
\text { Total }\end{array}$ & 3 & & & \\
\hline
\end{tabular}

Source: MPI Accreditation Data 2020

The data in table 3 shows that the total number of MPI lecturers is 25 people consisting of 8 permanent lecturers of study programs, 14 permanent lecturers with expertise outside the study program and 3 non-permanent lecturers. The functional positions of lecturers in the MPI study program consist of 2 people with functional positions as head lecturer, 7 people with lecturer positions, 13 people with functional assistant positions and 3 teaching staff.

\section{Lecturer to Student Ratio}

The ideal ratio of lecturers to students in the current year 2020 when referring to the APS 4.0 study program accreditation assessment matrix is 1:35 for the social and humanities study group. The calculation formula is the number of students divided by permanent lecturers whose expertise is in accordance with the core competencies of the study program. The total number of MPI students in 2020 is 473 while the number of lecturers with expertise according to core competencies is 8 people, so the ratio of lecturers to students is $473: 8=59$. Seeing this ratio shows that lecturers who teach courses in the MPI study program are less than ideal.

\section{Distribution of MPI Study Program Courses}

The MPI Study Program has a distribution of courses in each semester, the courses in the MPI study program consist of institutional, faculty, study program and elective courses. The eye distribution in the MPI study program is as follows

Table 4 : Institutional Element Subject Group

\begin{tabular}{ll}
\hline Total number of courses & $: 68$ Subjects \\
\hline Total number of credits & $: 156$ credits \\
\hline The total number of Institution courses & $: 17$ Courses \\
\hline The total number of credits for Institutional courses & $: 40$ credits \\
\hline The total number of faculty courses & $: 13$ Courses \\
\hline The total number of credits in the faculty course & $: 28$ credits \\
\hline The total number of Prodian courses & $: 32$ Courses \\
\hline The total number of credits for the Prodian course & $: 76$ credits \\
\hline
\end{tabular}




\begin{tabular}{ll}
\hline Total number of Elective courses & $: 6$ Courses \\
\hline The total number of credits for Elective courses & $: 12$ credits \\
\hline Number of credits of elective courses that must be taken & $: 6$ credits \\
\hline $\begin{array}{l}\text { Minimum Number of Course Credits That Students } \\
\text { Must Take }\end{array}$ & $: \mathbf{1 5 0}$ credits \\
\hline
\end{tabular}

The table shows that there are a total of 68 courses in the Islamic Educational Management Study Program with details of 17 institutional courses, 13 faculty courses, 32 study programs and 6 elective courses. The total credits that students must take is 150 credits.

\section{Lecturer Teaching Activity Data}

Lecturers have the obligation to carry out education, research and community service which is commonly called the tridharma of higher education. The composition of each of these elements is a minimum of 9 credits of education and research, a minimum of 3 credits of dedication and supporting elements, so that the total credits in each semester is a minimum of 12 credits and a maximum of 16 credits. There are teaching activities of 21 lecturers in odd semesters, with details of 8 Permanent Lecturers of Study Program (DTPS) and 13 Permanent Lecturers (DT). From these data, it was obtained that the average number of credits in DTPS was 12.4 credits, with the highest number of credits of 21 credits and the lowest of 6 credits. The average number of credits in this odd semester for DTPS is ideal, however, there are several study programs taught by lecturers that do not match their expertise.

The average number of credits for permanent lecturers with expertise outside the Islamic Educational Management Study Program is 7.24 credits. This value is far from the assumption that teaching in each semester is a minimum of 12 credits. Factors that influence this can occur because the permanent lecturer also teaches in other study programs, another factor that causes this to happen is because many institutional and faculty courses come from different scientific clumps so that they require lecturers with special specifications. Then the teaching activities of the lecturers in the even semester are as follows. There are teaching activities for 20 MPI lecturers in the even semester with the following details, the number of DTPS teaching in the even semester is 8 people. The average number of DTPS credits is 9.6 credits, with the highest credit for DTPS in the even semester is 18 credits and the lowest credit for this even semester is 6 credits. This average is ideal when referring to the minimum number of credits, but there are some lecturers who have more teaching credits.

Then the number of permanent lecturers with expertise outside the study program who teaches in the even semester is 12 people, the average number of credits in this even semester for permanent lecturers with expertise outside the study program is 5.9 credits with the highest number of credits is 13 credits and the lowest credit is 2 credits. This average is less than ideal when referring to the minimum number of credits and it can be 
concluded that there are excess lecturers with abilities outside the study program.

\section{Projecting Needs for Lecturers on Islamic Educational Management Study Program at Kediri in 2019-2029}

Projecting Needs for Lecturers on Islamic Educational Management Study Program at Kediri can be prepared after projecting the number of students. To find out the ideal number of lecturers in the Islamic Educational Management Study Program, the steps to be taken are as follows. 1) mapping the number of lecturers; 2) calculating the teaching load of MPI lecturers in each semester; 3) see the credit load of courses in each semester. Steps one and two have been done above, so the next step is to look at the course credits load of courses in each semester. The course credits load for each semester is as follows;

Table 5 : Recapitulation of Course credits for Islamic Educational Management Study Program

\begin{tabular}{|c|c|c|c|c|}
\hline & & Cou & Credit & \\
\hline \multirow{5}{*}{ Odd } & Semester & $\begin{array}{l}\text { Institution / } \\
\text { Faculty }\end{array}$ & $\begin{array}{c}\text { Study Program / } \\
\text { elect }\end{array}$ & $\begin{array}{l}\text { credits per } \\
\text { semester }\end{array}$ \\
\hline & I & 18 & 5 & 23 \\
\hline & III & 8 & 15 & 23 \\
\hline & $\mathrm{V}$ & 0 & 22 & 22 \\
\hline & VII & 4 & 10 & 14 \\
\hline \multicolumn{2}{|c|}{$\begin{array}{l}\text { Total Course Credit Odd } \\
\text { SMT }\end{array}$} & 30 & 52 & 82 \\
\hline \multirow{4}{*}{ Even } & II & 18 & 4 & 22 \\
\hline & IV & 4 & 20 & 24 \\
\hline & VI & 0 & 16 & 16 \\
\hline & VIII & 6 & 4 & 10 \\
\hline \multicolumn{2}{|c|}{ Total SMT Credit Even } & 28 & 44 & 72 \\
\hline \multicolumn{2}{|c|}{ Total credits } & 58 & 96 & 154 \\
\hline
\end{tabular}

Table 5 shows that the total credit load in the odd semester is 82 credits, consisting of 30 credits of institutional and faculty courses, then 52 credits of study program and elective courses. There are 11 courses in semester I with a total of 23 credits consisting of 9 institutional / faculty courses with a total of 18 credits and 2 study program subjects with a total of 5 credits.

In the third semester, there are 10 courses with a total of 23 credits consisting of 4 courses of institution / faculty with a load of 8 credits and 6 courses of study program with a load of 15 credits. Then in semester $\mathrm{V}$ there are 10 courses with a total of 22 credits, all of which are credits of study program courses. And finally, in semester VII, there are a total of 6 courses, a total of 14 credits, with details of 1 institution / faculty course weighing 4 credits and 5 study program / elective courses with a total of 10 credits. Next, the credit load in the even semester is as follows. 
While in Even Semester Table 5 shows that the total credit load in the even semester is 72 credits with a total of 30 courses, the details of the credit load for institution / faculty courses are 28 credits and the study program or elective courses are 44sks. The distribution of courses in the second semester is as follows, there are 9 institutional / faculty courses with a load of 18 credits and 2 study program courses with a load of 4 credits.

In the fourth semester there are 2 institutional / faculty courses with a load of 4 credits and 8 study program courses with a weight of 20 credits. Semester VI there are 7 study program / elective courses with a total load of 16 credits. In semester VIII, there is 1 institutional course with a load of 6 credits and 1 study program course with a load of 4 credits. The summary of the credit load in each semester is as follows.

Before calculating the projected needs for lecturers, the data needed is the projection of the number of study groups each year. Class projection is generated by dividing the projection of the number of students divided by the number of students in one class. The assumption used is 1 class containing 45 students, the results are as follows.

Table 6 : Projection of Islamic Educational Management Study Program Class

\begin{tabular}{ccc}
\hline Year & $\begin{array}{c}\text { Projected Number of } \\
\text { New Students }\end{array}$ & $\begin{array}{c}\text { Study group } \\
\mathbf{( 1 : 4 5 )}\end{array}$ \\
\hline 2021 & 165 & 4 \\
\hline 2022 & 186 & 4 \\
\hline 2023 & 209 & 5 \\
\hline 2024 & 234 & 5 \\
\hline 2025 & 262 & 6 \\
\hline 2026 & 293 & 7 \\
\hline 2027 & 327 & 7 \\
\hline 2028 & 365 & 8 \\
\hline 2029 & 407 & 9 \\
\hline
\end{tabular}

In table 6, the number of groups in 2021 is 4, in 2022 it remains the same as 4 groups, in 2023 there are 5 groups, in 20245 groups, in 2025 there are 6 groups, in 2026 there are 7 groups, in 2028 there are 8 groups and in 2029 totaled 9 groups. After knowing the number of classes, the next step is to calculate the total SKS in each semester, the following results are presented in diagram 1. 


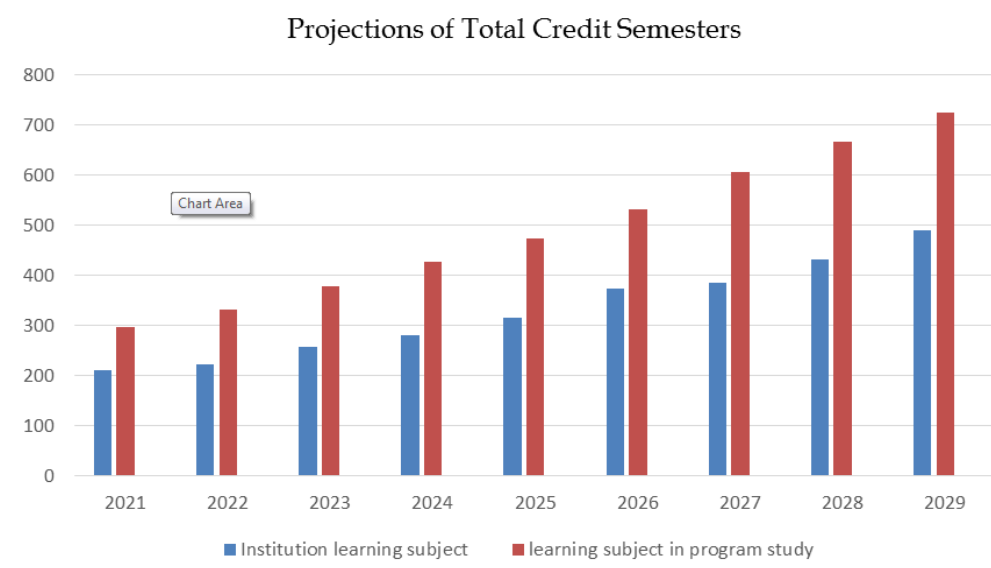

Figure 1 : Projections of Total Credit Semesters

In diagram 1, calculations are carried out based on the number of projected student groups in each generation, from these calculations the following results are obtained, the total number of credits in 2021 is 507, with details of 210 credits for institutional courses and 297 for study programs. credit is 554 with details of credit for institutional courses of 222 and study program courses of 332. In 2023 the total number of credits is 637 with a breakdown of credits for institutional courses of 258 and for study programs of 379. In 2024 the total number of credits is 708 with details of credit for institutional courses of 280 and for study programs of 428.

In 2025 the total number of credits will be 791 with the details of the credits for institutional courses of 316 and for study programs of 475. In 2026 the total number of credits is 907 with a breakdown of 374 credits for institutional courses and 533 for study programs. is 992 with a breakdown of credits for institutional courses of 386 and for study programs of 606. In 2028 the total number of credits is 1099 with details of credits for institutional courses of 432 and for study programs of 667. In 2029 the total number of credits is 1215 with details of credit subjects Institutional tuition is 490 and study program courses are 725 . From the results of calculating the number of credits for institutional and study program courses per year, a projection of the need for lecturers is carried out each year, the results are as follows in table 7

Table 7 : Projection of Needs for MPI Lecturers in 2021-2029

\begin{tabular}{|c|c|c|c|c|c|c|c|c|c|}
\hline \multirow[b]{2}{*}{ Year } & \multicolumn{2}{|c|}{$\begin{array}{c}\text { Total credits / } \\
\text { year }\end{array}$} & \multirow{2}{*}{$\begin{array}{l}\text { Teaching } \\
\text { Load/year }\end{array}$} & \multicolumn{2}{|c|}{ Ideal Lecturer } & \multicolumn{2}{|c|}{$\begin{array}{c}\text { Lecturer } \\
\text { Condition } \\
\end{array}$} & \multicolumn{2}{|c|}{ Lecturer Needs } \\
\hline & $\begin{array}{l}\text { Ins / } \\
\text { Fac }\end{array}$ & $\begin{array}{c}\text { Study } \\
\text { Progra } \\
\text { m / } \\
\text { Plhn } \\
\end{array}$ & & $\begin{array}{l}\text { Ins / } \\
\text { Fac }\end{array}$ & $\begin{array}{l}\text { Study } \\
\text { Program } \\
\text { / Plhn }\end{array}$ & $\begin{array}{l}\text { Ins / } \\
\text { Fac }\end{array}$ & $\begin{array}{l}\text { Study } \\
\text { Program } \\
\text { / Plhn }\end{array}$ & $\begin{array}{l}\text { Ins / } \\
\text { Fac }\end{array}$ & $\begin{array}{l}\text { Study } \\
\text { Program } \\
\text { / Plhn }\end{array}$ \\
\hline 2021 & 210 & 297 & 24 & 9 & 12 & 17 & 8 & -8 & 4 \\
\hline 2022 & 222 & 332 & 24 & 9 & 14 & 17 & 8 & -8 & 6 \\
\hline 2023 & 258 & 379 & 24 & 11 & 16 & 17 & 8 & -6 & 8 \\
\hline 2024 & 280 & 428 & 24 & 12 & 18 & 17 & 8 & -5 & 10 \\
\hline 2025 & 316 & 475 & 24 & 13 & 20 & 17 & 8 & -4 & 12 \\
\hline 2026 & 374 & 533 & 24 & 16 & 22 & 17 & 8 & -1 & 14 \\
\hline
\end{tabular}




\begin{tabular}{llllllllll}
$\mathbf{2 0 2 7}$ & 386 & 606 & 24 & 16 & 25 & 17 & 8 & -1 & 17 \\
\hline $\mathbf{2 0 2 8}$ & 432 & 667 & 24 & 18 & 28 & 17 & 8 & 1 & 20 \\
\hline $\mathbf{2 0 2 9}$ & 490 & 725 & 24 & 20 & 30 & 17 & 8 & 3 & 22 \\
\hline
\end{tabular}

The results of the calculation of the projected requirement for lecturers in the Islamic Educational Management Study Program at IAIN Kediri from 2021 to 2029 are as follows:

1. In 2021 there are a total of 210 credits of institutional courses and 297 credits of study programs. Assuming an ideal teaching load of 12 credits per semester, the teaching load for lecturers per year is 24 credits. From these results, the calculation is carried out by dividing the number of credits with the ideal load of lecturers per year. The result is the number of lecturers in institutional subjects as many as 9 people and for study programs as many as 12 people. With the current condition in Islamic Educational Management Study Program there are 17 lecturers in institutional subjects and 8 lecturers in study program courses, so there are an excess of 8 lecturers in institutional courses and a shortage of 4 lecturers in study program courses.

2. In 2022 there are a total of 222 credits of institutional courses and 332 credits of study programs. Assuming an ideal teaching load of 12 credits per semester, the teaching load for lecturers per year is 24 credits. The results obtained are 9 lecturers in institutional courses and 14 study program courses. With the current condition in Islamic Educational Management Study Program there are 17 lecturers in institutional subjects and 8 lecturers in study program courses, so there are an excess of 8 lecturers in institutional courses and a shortage of 6 lecturers in study program courses.

3. In 2023 there are a total of 258 credits of institutional courses and 379 credits of study programs. Assuming an ideal teaching load of 12 credits per semester, the teaching load for lecturers per year is 24 credits. The results obtained are 11 lecturers in institutional courses and 16 study program courses. With the current condition in Islamic Educational Management Study Program there are 17 lecturers in institutional subjects and 8 lecturers in study program courses, so there are an excess of 6 lecturers in institutional courses and a shortage of 8 lecturers in study program courses.

4. In 2024 there are a total of 280 credits of institutional courses and 428 credits of study programs. Assuming an ideal teaching load of 12 credits per semester, the teaching load for lecturers per year is 24 credits. The results obtained are 12 lecturers in institutional courses and 18 study program courses. With the current condition in Islamic Educational Management Study Program there are 17 lecturers in institutional subjects and 8 lecturers in study program courses, so there are an excess of 5 lecturers in institutional courses and a shortage of 10 lecturers in study program courses.

5. In 2025 there are a total of 316 credits of institutional courses and 475 credits of study programs. Assuming an ideal teaching load of 12 credits per semester, the teaching load for lecturers per year is 24 credits. The results obtained are the number of lecturers for institutional courses as many as 13 
people and for study program courses as many as 20 people. With the current condition in Islamic Educational Management Study Program there are 17 lecturers in institutional subjects and 8 lecturers in study program courses, so there are an excess of 4 lecturers in institutional subjects and a shortage of 12 lecturers in study program courses.

6. In 2026 there are a total of 374 credits of institutional courses and 533 credits of study programs. Assuming an ideal teaching load of 12 credits per semester, the teaching load for lecturers per year is 24 credits. The results obtained are the number of lecturers in institutional courses as many as 16 people and from the study program courses as many as 22 people. With the current condition in Islamic Educational Management Study Program there are 17 lecturers in institutional subjects and 8 lecturers in study program courses, so there is an excess of 1 lecturer in institutional courses and a shortage of 14 lecturers in study program courses.

7. In 2027 there are a total of 386 credits of institutional courses and 606 credits of study programs. Assuming an ideal teaching load of 12 credits per semester, the teaching load for lecturers per year is 24 credits. The results obtained are the number of lecturers in institutional courses as many as 16 people and from the study program courses as many as 25 people. With the current condition in Islamic Educational Management Study Program there are 17 lecturers in institutional subjects and 8 lecturers in study program courses, so there is an excess of 1 lecturer in institutional courses and a shortage of 17 lecturers in study program courses.

8. In 2028 , there are a total of 432 credits of institutional courses and 667 credits of study programs. Assuming an ideal teaching load of 12 credits per semester, the teaching load for lecturers per year is 24 credits. The results obtained are the number of lecturers in institutional courses as many as 18 people and from the study program courses as many as 28 people. With the current condition in Islamic Educational Management Study Program there are 17 lecturers of institutional subjects and 8 lecturers of study program courses, so there is a shortage of 1 lecturer in institutional courses and 20 lecturers of study program courses.

In 2029 there are a total of 490 credits of institutional courses and 725 credits of study programs. Assuming an ideal teaching load of 12 credits per semester, the teaching load for lecturers per year is 24 credits. The results obtained are the number of lecturers for institutional courses as many as 20 people and for study program courses as many as 30 people. With the current condition in Islamic Educational Management Study Program there are 17 lecturers of institutional courses and 8 lecturers of study program courses, so there is a shortage of 3 lecturers of institutional courses and 22 lecturers of study program courses. 


\section{CONCLUSION}

Based on the results of research conducted on the Projection of Needs for Lecturers on Islamic Educational Management Study Program, Tarbiyah Faculty, State Islamic Institute (IAIN) Kediri, it can be concluded that the projection of new students in the Islamic Educational Management Study Program in 2021 to 2029 shows a fluctuating increase, with an average growth rate of $12.06 \%$. The distribution of lecturers in the Islamic Educational Management Study Program at IAIN Kediri is that the number of lecturers for institutional subjects is 17 lecturers, while the lecturers who teach study program courses with expertise in accordance with the core competencies of the study program are 8 lecturers. There are 2 lecturers with functional positions as head lecturer in Islamic Educational Management Study Program, 7 lecturers with titles, 13 lecturers have functional assistant positions and 3 teaching staff. The average teaching hours of DTPS in odd semesters is 12.4 course credits, while in the even semester 9.6 credits. Further, the average teaching hours for permanent lecturers with expertise outside the study program in odd semesters is 7.29 credits while in the even semester 5.9 credits.

The Projection of Needs for Lecturers on Islamic Educational Management Study Program is that in 2021 the number of lecturers needed for institutional courses is 9 lecturers, while the number of lecturers for study program courses is 12 lecturers. In 2022 the number of lecturers needed for institutional courses is 9 lecturers, while the number of lecturers for study program courses is 14 lecturers. In 2023, the number of lecturers needed for institutional courses is 11 lecturers, while the number of lecturers for study program courses is 16 lecturers. In 2024, the number of lecturers in institutional courses is 12 lecturers, while the number of lecturers for study program courses is 18 lecturers. In 2025, the number of lecturers needed for institutional courses is 13 lecturers, while the number of lecturers for study program courses is 20 lecturers. In 2026, the number of lecturers needed for institutional courses will increase to 16 lecturers, while the number of lecturers needed for study program courses is 22 lecturers. In 2027, the number of lecturers needed for permanent institutional courses is 16 lecturers, while the number of lecturers for study program courses will increase to 25 lecturers. In 2028, the number of lecturers needed for institutional courses will increase to 18 lecturers, while the number of lecturers for study program courses is 28 lecturers. In 2029 the number of lecturers in institutional courses will increase to 20 lecturers, while the number of lecturers needed for study programs is 30 lecturers. In 2028, the number of lecturers needed for institutional courses will increase to 18 lecturers, while the number of lecturers for study program courses is 28 lecturers. Thus, in 2029 the number of lecturers in institutional courses will increase to 20 lecturers, while the number of lecturers needed for study programs is 30 lecturers. 


\section{REFERENCES}

Anwar, H. (2016). Proyeksi Kebutuhan Dosen Prodi Manajemen Pendidikan Islam Fakultas Ilmu Tarbiyah dan Keguruan IAIN Sultan Amai Gorontalo (Tahun Akademik 2016/2017-2020/2021). Tadbir: Jurnal Manajemen Pendidikan Islam, 4(2), 12-36.

Armstrong, J. S., \& Green, K. C. (2018). Forecasting Methods and Principles: Evidence-based checklists. Journal of Global Scholars of Marketing Science, 28(2), 103-159. https:// doi.org/10.1080/21639159.2018.1441735

Chindia, E. W., \& Wainaina, G. (2014). Forecasting Techniques, Operating Environment and Accuracy of Performance Forecasting for Large Manufacturing Firms in Kenya. International Journal of Managerial Studies and Research, 02(7), 18-100.

Hamidi, D. Z. (2017). Analisis Jumlah Kebutuhan Dosen Tetap di Perguruan Tinggi melalui Pendekatan Forecasting Jumlah Mahasiswa. Jurnal Ekonomak, 3(2), 10-18.

Hermawan, I. K. D. (2014). Menyusun Proyeksi Pendidikan, Metode, dan Aplikasi Proyeksi Sekolah Dasar Tahun 2012/2013-2020/2021. Jurnal Pendidikan dan Kebudayaan. 20(2), 261-280.

Locke, E., \& Latham, G. (1990). A Theory of Goal Setting E Task Performance. Englewood Cliffs, NJ, US: Prentice-Hall, Inc.

Makridakis, S., Hyndman, R. J., \& Petropoulos, F. (2020). Forecasting in social settings: The state of the art. International Journal of Forecasting, 36(1), 1528. https:// doi.org/10.1016/j.ijforecast.2019.05.011

Mangkunegara, A. A. P. (2003). Perencanaan dan Pembangunan Sumber Daya Manusia. Jakarta: Refika Aditama.

Nawawi, H. (2003). Perencanaan SDM untuk Organisasi Profit yang Kompetitif. Yogyakarta: Gadjah Mada University Press.

Rohman, M. (2016). Problematika Guru dan Dosen dalam Sistem Pendidikan di Indonesia. Cendekia: Jurnal Kependidikan dan Kemasyarakatan, 14(1), 49-71.

Priyono, P. (2010). Manajemen Sumber Daya Manusia. Sidoarjo: Zifatama Publisher.

Qomar, M. (2007). Manajemen Pendidikan Islam. Jakarta: Erlangga.

Rakhimov, I. B. R. A. K. H. I. M. J. O. N., \& Kankarej, M. (2015). Forecasting the number of students in general education in University College using mathematical modelling. Journal of Mathematical Sciences: Advances and Applications, 32, 57-71.

Setijaningsih, H. T., \& Handoyo, S. E. (2012). Penentuan Jumlah Dosen. Karya Ilmiah Dosen.

Setyadin, B. (2005). Dasar-Dasar Penelitian Ilmiah. Malang: Lembaga Penelitian UM.

Suryadi, S. (2005). Analisis Kebutuhan Guru untuk Mengantisipasi Dampak Pensiun Guru yang Direkrut selama Pelaksanaan Inpres SD dan Wajib Belajar 6 Tahun (Studi Pada Dinas Pendidikan Propinsi Jawa Barat). Jurnal Administrasi Pendidikan, 3(2), 83-113.

Terry, G. (1977). Prinsip-Prinsip Manajemen. Jakarta: Bumi Aksara. 
Triwiyanto, T., Kusumaningrum, D. E., \& Gunawan, I. (2017). Proyeksi Ketersediaan, Kebutuhan, Dan Distribusi Guru Sekolah Menengah Pertama Di Kota Batu. Malang: FIP UM.

Undang - Undang Republik Indonesia No.14 Tahun 2005 Tentang Guru dan Dosen. (2005). Jakarta.

Widiansyah, A., Sutjipto, S., \& Mukhtar, M. (2019). Recruitment and Selection Model Lecturer Based on Islamic Boarding Schools. International Journal of Engineering and Advanced Technology, 8(5C), 420-426. https://doi.org/10.35940/ijeat.E1059.0585C19 